\title{
Influence of oceanographic processes on the early life stages of the blue shrimp (Litopenaeus stylirostris) in the Upper Gulf of California
}

\author{
L.E. Calderon-Aguilera ${ }^{a, *}$, S.G. Marinone ${ }^{a}$, E.A. Aragón-Noriega ${ }^{\text {b,1 }}$ \\ ${ }^{a}$ Centro de Investigación Cientifica y Educación Superior de Ensenada, Km 107 Carretera Tijuana-Ensenada, Ensenada, \\ Baja California, 22860 Mexico \\ ${ }^{\mathrm{b}}$ Centro de Investigaciones Biológicas del Noroeste, Apdo. Postal 349 Guaymas, Sonora, 85400 Mexico
}

Accepted 29 October 2002

\begin{abstract}
The possible relationship between circulation patterns and the recruitment of early stages of penaeid shrimp in the Upper Gulf of California was explored by collecting postlarvae (mesh size $0.505 \mathrm{~mm}$ ) simultaneously in two locations, one off the coast of Sonora (Golfo de Santa Clara: $31^{\circ} 44^{\prime} 49^{\prime \prime} \mathrm{N}-114^{\circ} 33^{\prime} 12^{\prime \prime} \mathrm{W}$ ) and the other off the Baja California peninsula (San Felipe: $31^{\circ} 11^{\prime} 8.3^{\prime \prime} \mathrm{N}-114^{\circ} 53^{\prime} 13.9^{\prime \prime} \mathrm{W}$ ) during two complete fortnightly cycles (July 12-27, 1995 and June 30-July 16, 1996). Individuals with cephalothoracic length from 0.8 to $3.91 \mathrm{~mm}$ without a clear size-increasing pattern were found throughout the sampling period, suggesting continuous recruitment to the area. The circulation in the study area was simulated with a threedimensional baroclinic model forced with tides and climatological hydrography at the mouth of the Gulf of California, and winds and heat and freshwater fluxes at the sea-air interface. Spawning stock surveys have shown that maximum concentration of mature females is near the coast of Sonora (mainland Mexico). The model predicts surface currents of about $8 \mathrm{~cm} \mathrm{~s}^{-1}$ and suggests that postlarvae found off the coast of the peninsula may come from a different reproductive unit than those found off the mainland coast. This may explain why postlarvae found in Golfo de Santa Clara (mainland) are larger (and, presumably, older) than those found in San Felipe (Baja California). Possible relationships among circulation patterns, lunar cycle, former Colorado River runoffs and time of spawning are discussed.

(C) 2002 Elsevier Science B.V. All rights reserved.
\end{abstract}

Keywords: Shrimp; Postlarvae; Recruitment; Effective spawning; Oceanographic processes; Baroclinic model; Mexico; Gulf of California

\section{Introduction}

The early life stages of most marine species are severely affected by environmental factors such as currents, temperature and salinity. Eggs and larvae are

\footnotetext{
* Corresponding author.

${ }^{1}$ Mailing address: P.O. Box 43-4844 San Diego, CA 921434844, USA.
}

advected to or from nursery areas, until they have the motile capabilities to search for a favorable habitat. Penaeid shrimps spend their adult life and spawning stage offshore. The eggs hatch soon (14 h) after they are spawned and the shrimp pass quickly through a series of planktonic stages (nauplius that feeds on its own egg sac, protozoea and mysis); finally, after 1014 days, they migrate as postlarvae to coastal and estuarine waters (García and Le Restre, 1981). The 
reason for this behavior is not clear, and many explanations have been proposed. Wickins (1976) summarized the mechanism by which postlarvae penetrate estuaries. As the tide rises, a salt wedge moves inward along the bottom of the estuary and the postlarvae leave the bottom in response to increased salinity. They are carried up the estuary in the saline water (the freshwater flows seaward at the surface) and when the tide reaches its peak and turns to ebb the postlarvae settle to the bottom in response to the decreased salinity. Rothlisberg et al. (1995) suggested that postlarval migration is instigated by the change in pressure as the tide begins to flood. This tidal activity traps the postlarvae in the coastal zone and moves them progressively toward the coast in a ratchetlike fashion during the first $3 \mathrm{~h}$ of each flood tide.

There are very few oceanographic studies in the northernmost part of the Gulf of California, the region delineated by an imaginary line from San Felipe on the peninsula to Puerto Peñasco on the mainland, known as the Upper Gulf of California (UGC; Lavín et al., 1997a). In spite of the drastic changes that the Colorado river damming caused to the delta and UGC, the blue shrimp Litopenaeus stylirostris and the brown shrimp Farfantepenaeus californiensis recruit and grow in this area, although they are tropical species, preferring low salinity during their early life stages (García and Le Restre, 1981). Salinity in the UGC is higher (38 psu) than in the northern Gulf (34.5 psu), resulting in inverse estuarine conditions (Carbajal et al., 1997; Lavín et al., 1998; Lavín and Sánchez, 1999; Alvarez-Borrego, 2000).

In the last few years, there has been an increasing research effort in the area, mainly in the northern Gulf, the area comprised between the Midriff Islands (Angel de la Guarda and Tiburón Islands) and the UGC. The northern Gulf's large-scale circulation is dominated by a reversing seasonal gyre (cyclonic in summer and anticyclonic in winter) as documented by Lavín et al. (1997b) with satellite-tracked drifters (ARGOS) measurements, and by Carrillo et al. (2002) from geostrophic calculations. The cyclonic gyre lasts about 4 months (June to September) and the anticyclonic gyre lasts about 6 months (November to April; Palacios-Hernández et al., 2002). Both observations and numerical modeling suggest that this is the major feature of the circulation pattern in the northern Gulf.
The assumption that the circulation pattern in the UGC during the summer is cyclonic is a gross approximation of the complicated hydrography of the area. Based on that circulation pattern, it was expected that postlarvae (PL) off the mainland coast would be younger (smaller) than those off the Baja California peninsula. However, Aragón-Noriega and CalderonAguilera (2001) consistently found younger PL (mean age $=22$ days old) off the peninsula coast than off the mainland coast (mean age $=28$ days old). They concluded that the PL from the peninsula and those from the mainland came from different reproductive units, and/or there must be another circulation pattern.

In this work, we focus on the blue shrimp because it comprises up to $67 \%$ of total shrimp catches from the UGC. It has been found through regular sampling that spawning blue shrimp concentrate mostly off the mainland coast of the Gulf (Aragón-Noriega et al., 1999). We describe the migratory pattern of the blue shrimp and discuss the possible relationships between migration patterns, currents and lunar cycles, under the hypothesis that the life cycle of shrimp in this area differs from the spawning and migratory pattern generally accepted for this species. On one hand, larvae migrate toward the Colorado Delta, which is an inverse estuary with higher salinity than the usual habitat for the blue shrimp. On the other hand, postlarvae found off the peninsula coast may not come from the massive spawning stock located near the mainland coast, as might be expected. Although regular sampling surveys during the shrimp fishery closed season by the National Institute of Fisheries has located the spawning stock off the mainland coast, additional unidentified populations may exist in the region. An earlier motivating question of this study was to assess the impact of postlarvae fishing for culture to recruitment to the spawning population, an important issue in conservation biology and resource management.

\section{Materials and methods}

Shrimp postlarvae (PL) were sampled daily during two periods and in two locations: July 12-27, 1995 and June $30-J u l y ~ 16,1996$, off the peninsula near San Felipe $\left(31^{\circ} 11.175 \mathrm{~N} ; 114^{\circ} 53.239 \mathrm{~W}\right)$, and off Santa Clara near the mainland $\left(31^{\circ} 41.169 \mathrm{~N} ; 114^{\circ} 30.141 \mathrm{~W}\right.$; Fig. 1). In both years, the starting date of sampling 


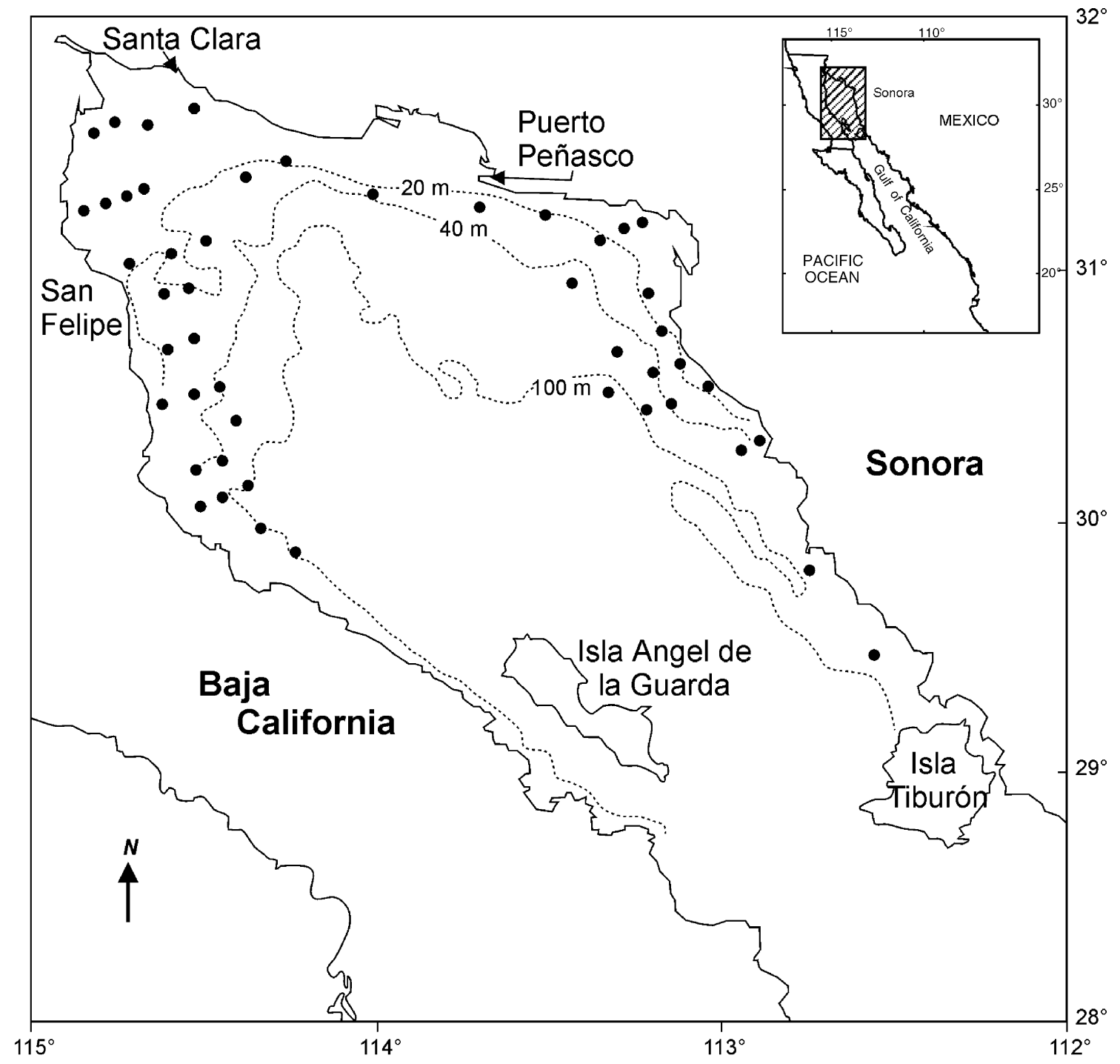

Fig. 1. Study area, showing the two coastal locations for shrimp postlarvae collection and sampling stations of spawning units (Filled dots). Depth contours in meters; note the broader shelf off the Sonoran coast.

coincided with full moon and, therefore, with spring tides. Sampling was done simultaneously in both locations by two crews using identical gear $(550 \mu$ mesh size). Ten-minute tows were conducted manually every hour during the flood tide $(n=5)$. Subsurface sea temperature was recorded every hour for the duration of each study period. The abundance of PL was averaged by "tidal day," i.e., total PL sampled during the two tidal cycles in a lunar day ( $24 \mathrm{~h} 50 \mathrm{~min})$. Tides in the UGC are clearly semidiurnal. During 1995, tides were as low as $-8.9 \mathrm{~m}$ (referred to the lower low mean sea level) and as high as $5.59 \mathrm{~m}$. In 1996, tides ranged from -8.94 to $5.47 \mathrm{~m}$. Species identification followed Mair (1979) and Calderón-Pérez et al. (1989). Carapace length of PL was measured with the aid of a calibrated micrometer. Differences in postlarvae relative abundance were estimated through one-way analysis of variance, following a completely randomized experimental design, considering locations as factors and tidal days as levels. 
Spawning stock distribution and abundance data come from surveys (June and July 1995; June, July and August, 1996) conducted with commercial fishery gear (23.4 m boat, $624 \mathrm{HP}$; see details in AragónNoriega et al., 1999).

To simulate the circulation in the study area, the Hamburg Shelf Ocean Model (HAMSOM) was used. This is a layerwise vertically integrated baroclinic model and it is described in detail in several papers (Backhaus, 1983, 1985; Crean et al., 1988; Stronach et al., 1993; Marinone et al., 1996; Rady et al., 1998). Twelve layers are used in the vertical with nominal lower levels at 10, 20,30,60,100, 150, 200, 250, $350,600,1000$ and $4000 \mathrm{~m}$. The model equations are solved semi-implicitly with fully prognostic temperature and salinity fields, thus allowing time-dependent
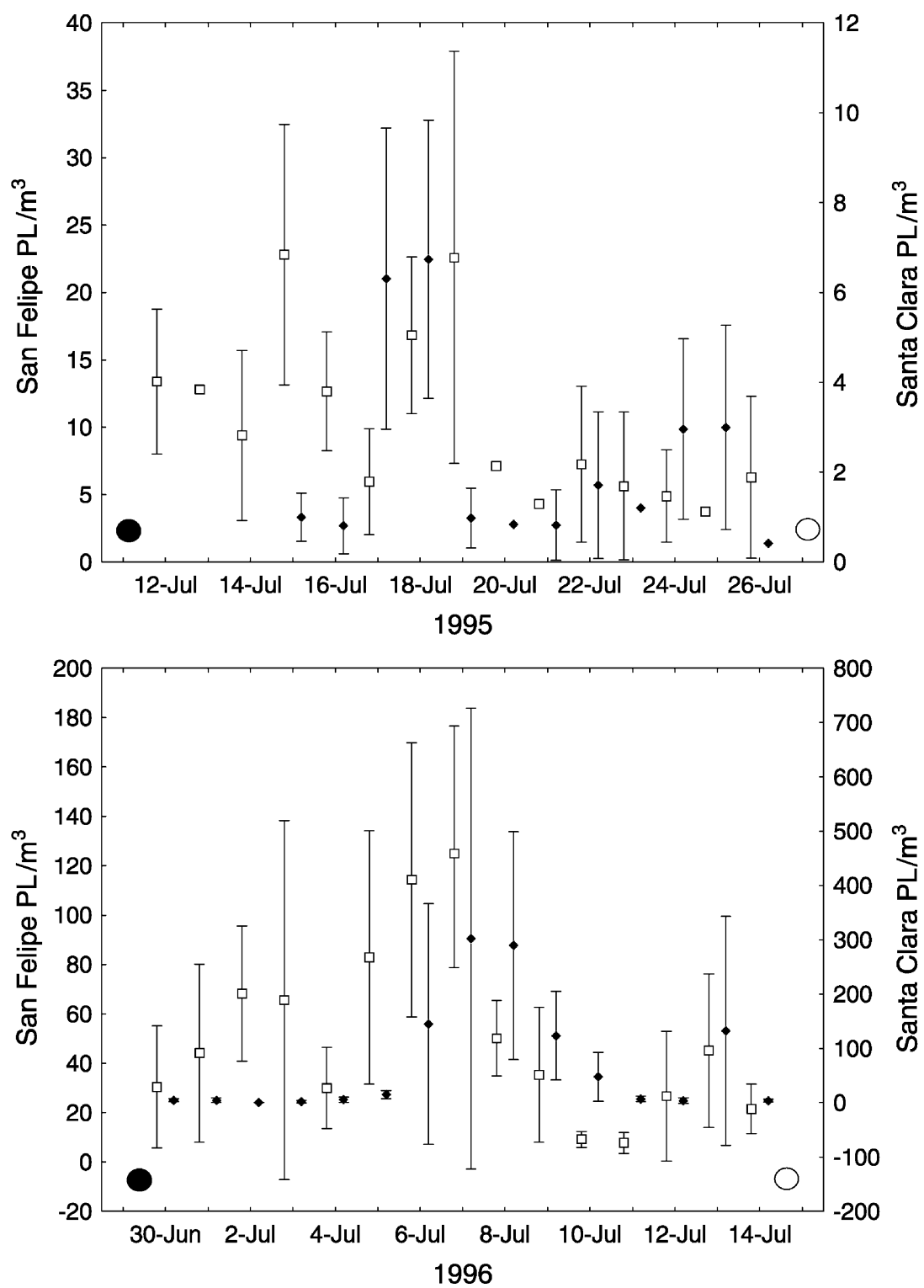

Fig. 2. Mean \pm 0.95 confidence interval of postlarvae abundance $\left(\mathrm{PL} \cdot \mathrm{m}^{-3}\right)$ by tidal day in San Felipe ( $\square$ ) and Santa Clara ( $\left.\bullet\right)$ in 1995 and 1996. Note that the scale is different both in locations and in years. 
baroclinic motion. The model domain has a mesh size of $2.5^{\prime} \times 2.5^{\prime}(\sim 3.9 \times 4.6 \mathrm{~km})$. The model is forced with the seven most important tidal constituents (M2, S2, N2, K2, K1, O1 and P1).

The temperature and salinity fields are prescribed at the Gulf of California's entrance (not shown in the figures) using the available historical data. Boundary grid points are interpolated for each month of the year by means of objective analysis, and then least-square fitted to annual and semiannual harmonics. At the sea surface, a simple up- and down-Gulf sinusoid seasonal wind is imposed with amplitude of $5 \mathrm{~m} \mathrm{~s}^{-1}$, with maximum up-Gulf in August. Heat and freshwater fluxes were calculated with bulk formulae as in
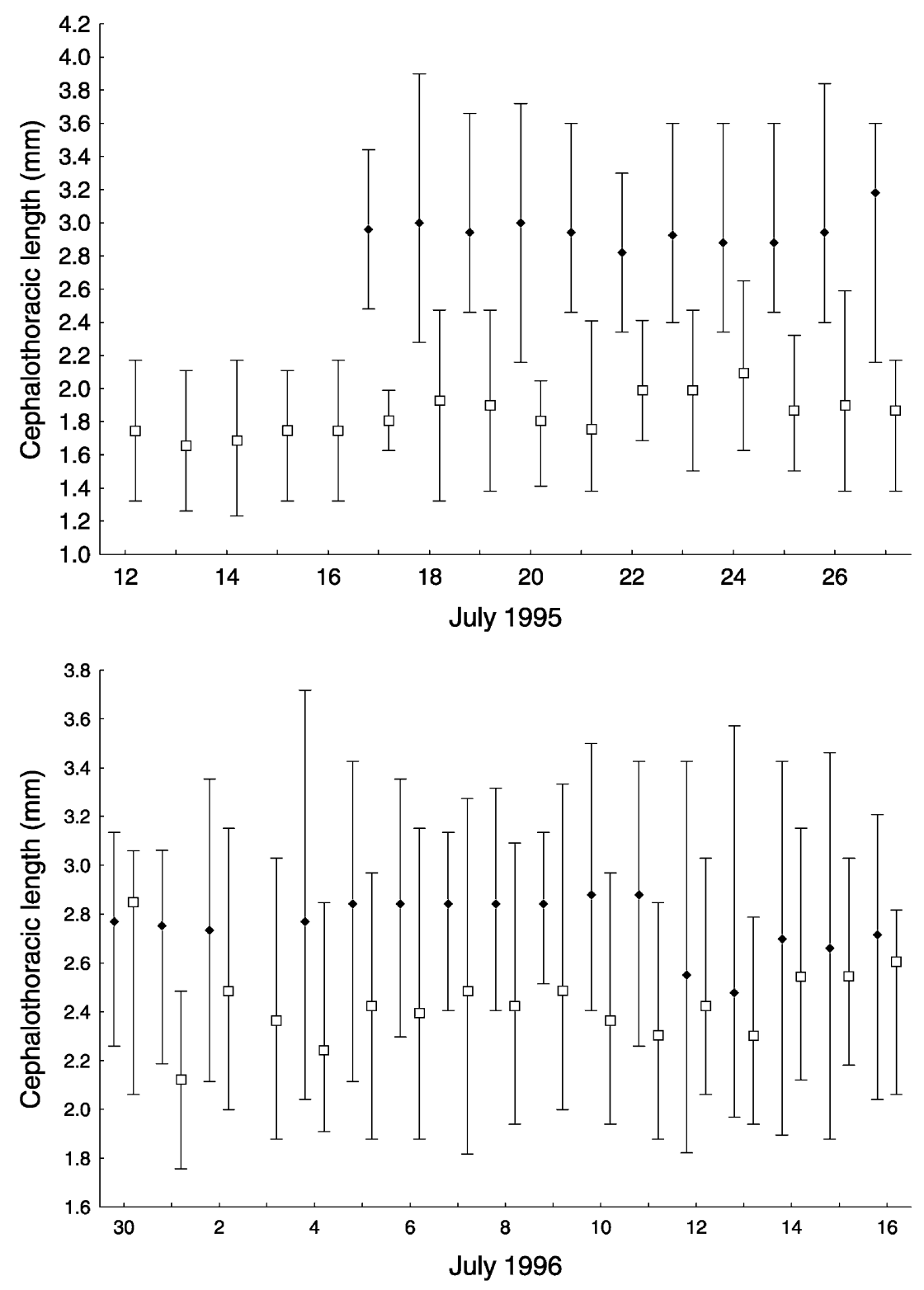

Fig. 3. Mean \pm 0.95 confidence interval of the cephalothoracic length (mm) of blue shrimp Litopenaeus stylirostris postlarvae in San Felipe ( $\square$ ) and in Santa Clara (४), in 1995 and 1996. 

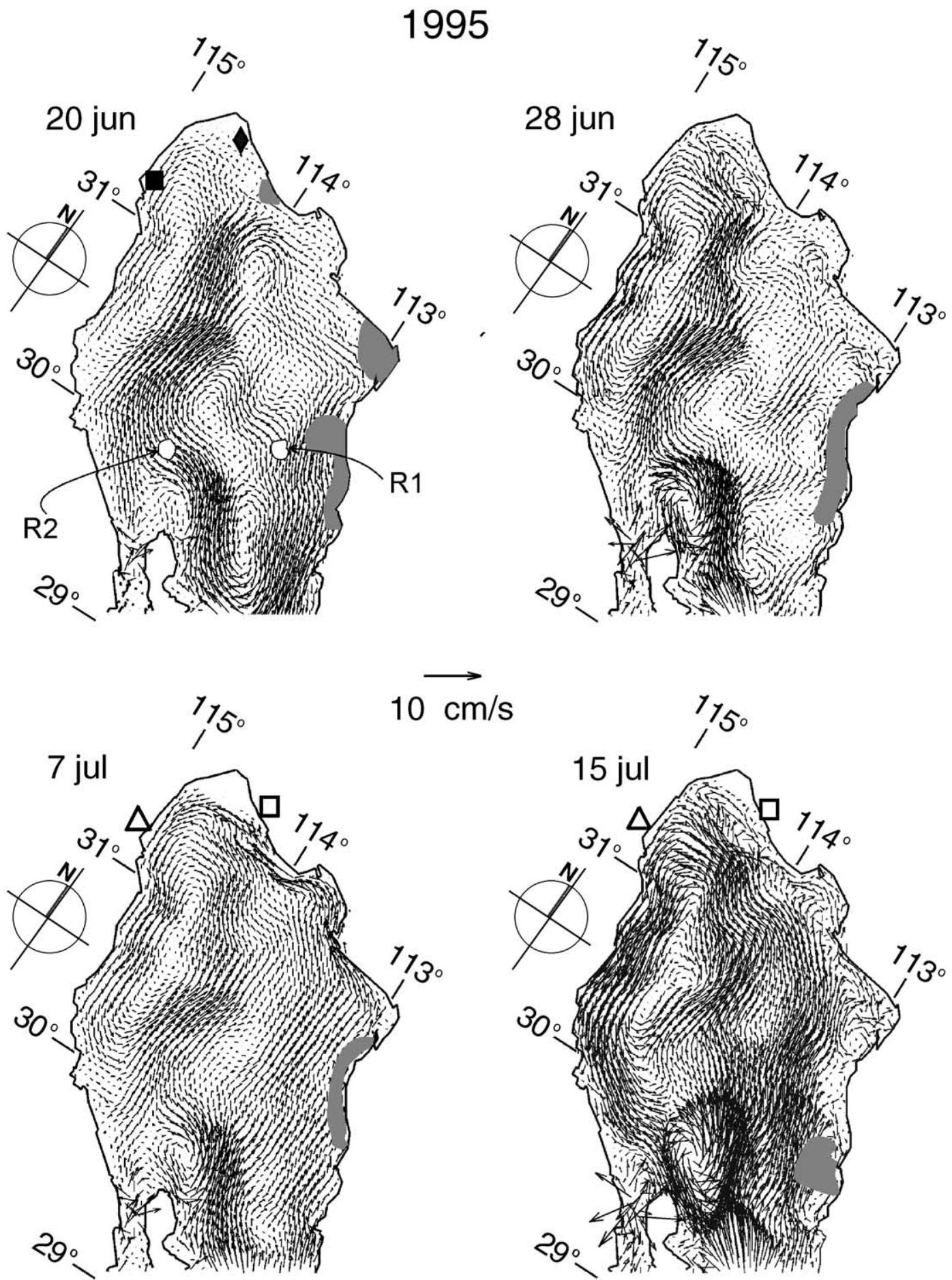

Fig. 4. Baroclinic model output of the circulation pattern in the northern Gulf of California in 1995. Shaded areas represent spawning stock usual location on that time of the year; Postlarvae collection sites are also indicated ( $\square$ San Felipe, $\diamond$ Golfo de Santa Clara). 

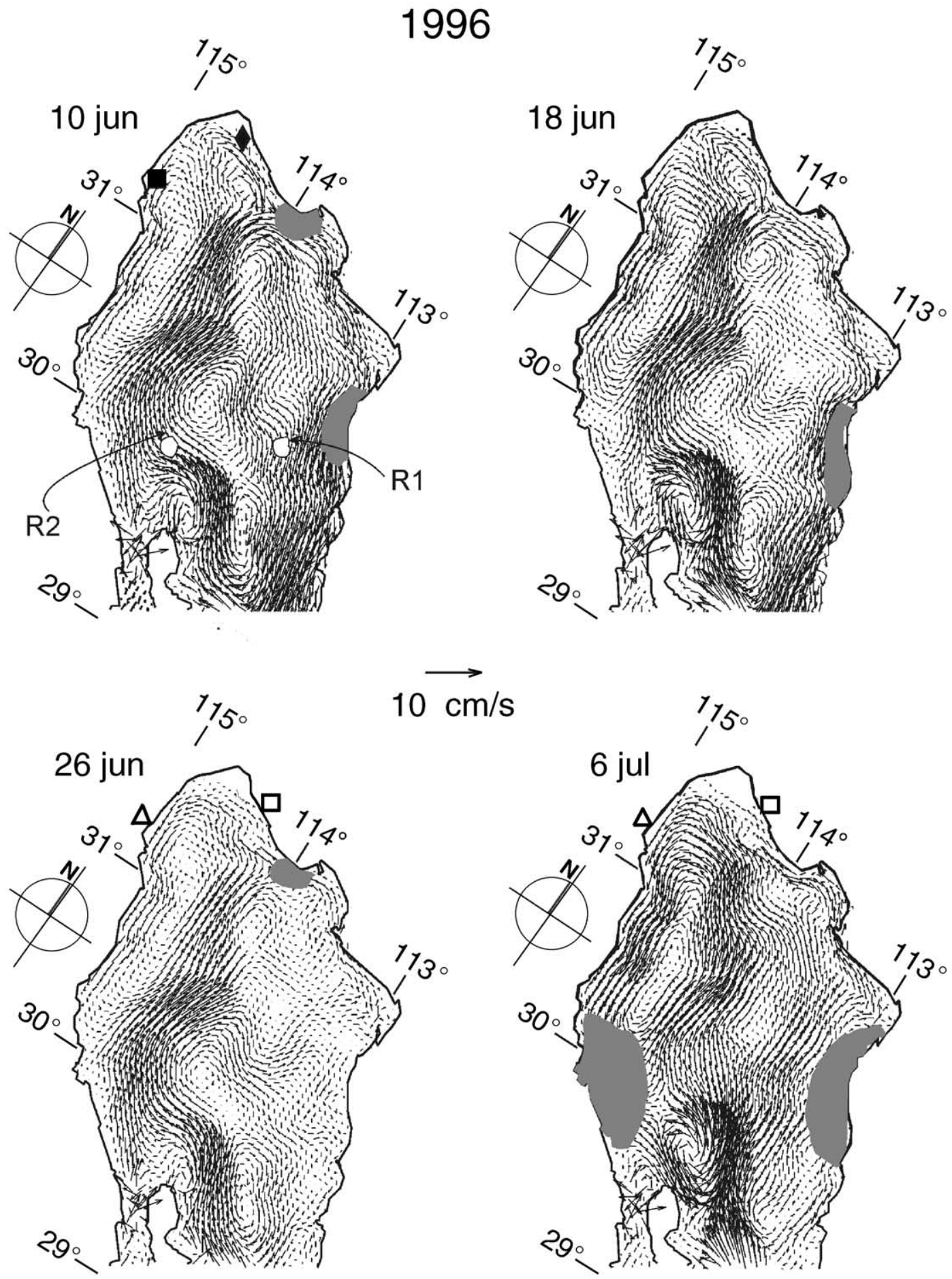

Fig. 5. Baroclinic model output of the circulation pattern in the northern Gulf of California in 1996. Shaded areas represent spawning stock usual location on that time of the year; Postlarvae collection sites are also indicated ( $\square$ San Felipe, $\diamond$ Golfo de Santa Clara). 


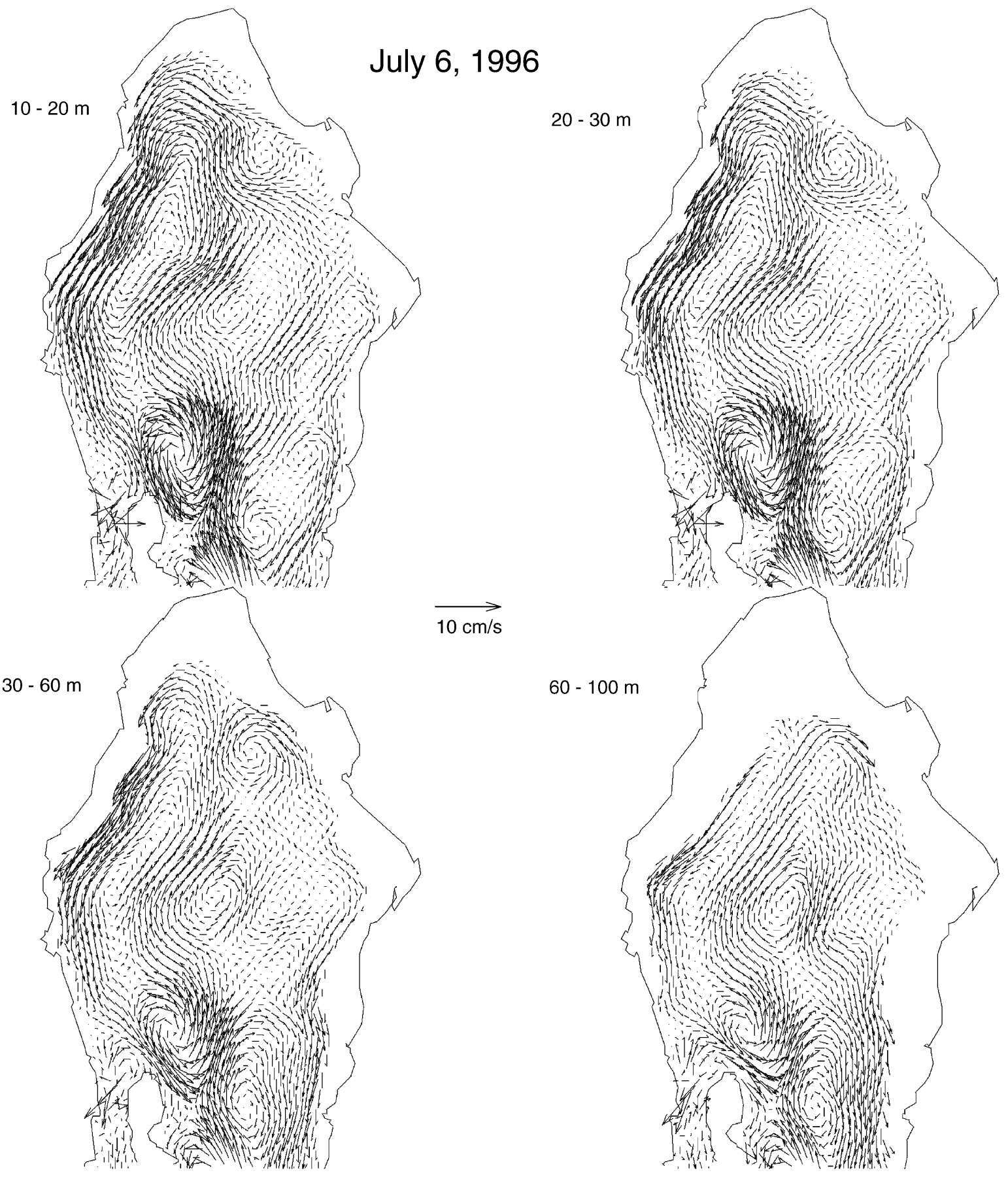

Fig. 6. Circulation pattern in the northern Gulf of California on July 6, 1996, at four different depth layers. 
Castro et al. (1994) and the meteorological parameters (air temperature, humidity, cloudiness, etc.), from six stations around the Gulf, were also fitted to seasonal functions to calculate the different fluxes. These flux calculations use the calculated model SST. Finally, at the open boundary, we implemented radiation boundary conditions (Orlanski, 1976; Chapman, 1985) on the dynamical variables and a sponge was also applied to all variables in the first 10 grid rows of the domain. After running the model, time series of filtered currents (low-pass filter) were constructed for the period of spawning and larvae distribution (June-July).

\section{Results}

Mean sea temperature was $30{ }^{\circ} \mathrm{C}$ in 1995 , and daily temperature varied from 28.7 to $31.1{ }^{\circ} \mathrm{C}$. In 1996 , it was essentially the same (mean sea temperature $=30{ }^{\circ} \mathrm{C} ; 28.1-31.1{ }^{\circ} \mathrm{C}$ ).

The postlarvae abundance varied significantly $(p<0.0005)$ during the 2-week tidal cycle in both locations. Postlarval abundance was higher in San Felipe than in Santa Clara in 1995; in 1996, the pattern was reversed (Fig. 2). The PL abundance showed sharp variations during the study period that were correlated not with the tidal (lunar) cycle, but with local strong winds. This is remarkable because if spawning is correlated to the lunar cycle, a peak of abundance would be expected either at the beginning or at the end of the lunar cycle. Therefore, there may be multiple spawning events during the season. For example, on July 8, 1996, approximately 8832 PL were collected at $1900 \mathrm{~h}$ at Golfo de Santa Clara, when there were strong winds at the sampling site, but no PL were caught just $1 \mathrm{~h}$ later at exactly the same place (Note wide interval around the mean abundance of that day in Fig. 2).

Postlarvae carapace length was consistently shorter in San Felipe (mean $=1.81 \mathrm{~mm}, \mathrm{SD}=0.24, n=2038$, in 1995 ; mean $=2.46 \mathrm{~mm}, \mathrm{SD}=0.31, n=1657$, in 1996) than in Santa Clara (mean $=3.02 \mathrm{~mm}, \mathrm{SD}=0.32$, $n=906$, in 1995; mean $=2.77 \mathrm{~mm}, \mathrm{SD}=0.29$, $n=1562$, in 1996). Fig. 3 shows that the PL carapace median length remains more or less steady during the study period and, therefore, a size-increasing pattern cannot be identified, i.e., there is not a progression of the PL modal length.

\section{Circulation}

Time series (snapshots) of filtered surface currents are presented in Figs. 4 and 5 for 1995 and 1996, respectively. The dates were chosen assuming that postlarvae collected in the nursery area had hatched at least 14 days before they were collected. Both periods show very similar circulation patterns. The most obvious features are that during the first 7 days of both years, there is a strong northward flow from Isla Angel de la Guarda toward Golfo de Santa Clara and a southward flow at both coasts. Then the circulation pattern progresses to develop a large basin-size cyclonic gyre.

The circulation pattern is very similar within the water column. As an example, Fig. 6 shows four different layers of the model for July 6, 1996. The direction of the currents is vertically the same, but the magnitude decreases with depth.

\section{Discussion}

The role of the UGC as a nursery area for many species as well as the presence of many endemic and endangered species motivated the Mexican Government to declare it as a Biosphere Reserve in 1993. In this work, we found shrimp postlarvae from reproductive units outside the reserve, but there are huge variations of abundance between the mainland coast and the peninsula coast due to physical factors such as wind stress and residual currents.

The transport of larvae is a function of the physics of the ocean circulation, the behavior of larvae, and the duration of these planktonic stages. Heron et al. (1994) found that the larval stages of Penaeus merguensis offshore are controlled in their vertical migration by light; on the other hand, the postlarvae in the estuaries become more active on the incoming tide and are therefore cued by some physical property of the tide.

The presence of a wide range of postlarval sizes (and, presumably, ages) is probably due to continuous recruitment to the area and not to a lack of food resources because nutrients are abundant in that area (Hernández-Ayón et al., 1993).

In Figs. 4 and 5, the proposed larval release points (R1 and R2) were based on presumed spawning sites and on the assumption that spawning is synchronic at 
both sites. In 1995, reproductive products from R2 would supply PL to San Felipe by advection throughout the tidal cycle; meanwhile, those larvae from R1 would go southward during the first days (Fig. 4a) and then turn northward to Golfo de Santa Clara by July 7 . According to the simulated circulation pattern, only larvae spawned during late June and early July in the area marked R1 could reach Golfo de Santa Clara. Both locations, R1 and R2, can regularly supply PL to Golfo de Santa Clara, but larvae from R1 travel southward first and then northward and, therefore, take longer to get there. This may explain why PL were older (larger) in Santa Clara than in San Felipe, but it should be taken cautiously because the model is based on idealized winds.

In 1996, the model predicts basically the same circulation patterns. However, in this case, currents seem to also favor the advection of PL from R2 to Golfo de Santa Clara. It is remarkable that even when PL found in Golfo de Santa Clara are again larger (older) than those found in San Felipe as in 1995, sizes are not significantly different (Fig. 4b).

Also, the horizontal currents at different levels of the water column remain in the same direction (see Fig. 6); therefore, the advection just described remains valid. The possible vertical migration of larvae would not change the described horizontal migration pattern. First shrimp larval stages have limited motion capacity and positive buoyancy, so they are probably advected in the upper layer. When they reach the PL stage, they can migrate vertically to take advantage of residual currents. In this way, they can be transported to more favorable nursery areas.

It should be pointed out that the numerical model used to simulate the circulation pattern in the study area does not consider scales shorter than semidiurnal cycles and the grid scale is far larger $(3.9 \times 4.6 \mathrm{~km})$ than the sampled area. Nevertheless, the geographic distribution of blue shrimp spawning stock in the UGC seems to be coupled with the circulation pattern. One group of mature females would migrate during the Spring and Summer seasons to the Sonora coast and another group would remain close to the peninsula coast, as we are suggesting. Nursery takes place from June to August in the UGC and Colorado Delta, and juveniles would migrate later to deeper waters. Results of the model used in this work support that hypothesis, but it should be viewed carefully as wind forcing is not realistic at short time scales. We also assume that reproductive units spawn simultaneously at both releasing points (R1 and R2 in Figs. 4 and 5), which is reasonable considering that oceanographic conditions are similar in the region.

Rothlisberg (1982) estimated through field observations that penaeid larvae in the Gulf of Carpentaria could travel $70-100 \mathrm{~km}$ in 14 days. He found that the day-night differences in vertical distribution of larvae, although present, were less distinct and the zoea larval stage was seen even at the surface at night. The day-night pattern for mysis stage larvae was even less distinct. Although spread throughout the water column, they appeared to be slightly more concentrated at or near the surface at night. Postlarvae numbers were low, and they were near the surface during the entire diet period. They were more abundant in the surface stratum at night. This author speculates that the postlarvae movements based on sampled vertical distributions would have closely paralleled the bottom currents because so much of the time was spent in the lower parts of the water column. Here we found that the vertical migration would not change the horizontal larvae excursion; therefore, advection of larvae would be the result of the upper layer's residuals currents. This is consistent with what has been observed with other shrimp species (Rothlisberg, 1982; Rothlisberg et al., 1983, 1996; Rogers et al., 1993). However, the effects of migration-tide interaction cannot be isolated from other dispersal processes such as tidal, wind- and density-driven circulations as well as from horizontal turbulent eddies and shear diffusion.

Ouellet and Lefaivre (1994) found that larvae of Pandulus borealis 12 days old could be horizontally advected $66 \mathrm{~km}$. In this study, we found PL that had been spawned about 20-28 days before and could have come as far away as $\sim 200 \mathrm{~km}$ (Fig. 1). Assuming a mean residual current speed of $8 \mathrm{~cm} \mathrm{~s}^{-1}$, as obtained from the model, reproductive products released near point R2 could be the PL collected in the UGC.

Many authors have suggested that shrimp stocks spawn in response to some physical signal (Rothlisberg, 1982; Hill, 1994; Ouellet and Lefaivre, 1994). The blue shrimp is known for its low-salinity preference during its postlarvae and juvenile stage (Edwards, 1978; Mair, 1980; García and Le Restre, 1981; Mathews, 1981; Mair et al., 1982), presumably because 
osmoregulation requires energy. Prior to the Colorado damming, the delta had low salinity during June and July (Lavín and Sánchez, 1999) and Carbajal et al. (1997) estimated the region of freshwater influence of the Colorado River in $80 \times 100 \mathrm{~km}$. This would be the area from the Delta southward to San Felipe (see Fig. $1)$.

Although the UGC and Delta are now hypersaline, larvae still migrate to this area. Perhaps there is some sort of memory in the population, and when currents, lunar phase and (formerly) river runoff coincide, spawning took place. In a recent review, Warner et al. (2000) suggest that larval accumulation results from some aspect of larval behavior in response to a common near-shore physical feature and that the final movement onshore might also be the result of simple behaviors combined with other physical features.

The time since the Colorado River damming, 66 years ago, represents a short evolutionary time period, but blue shrimp populations of the UGC seem to have adapted to these conditions. Holtschmit and Romero (1991) observed maturation and spawning of blue shrimp under hypersaline conditions, but nauplii production was up to $75 \%$ less than under normal conditions. There is some evidence that suggests that the populations of the UGC are genetically segregated from those of the southern Gulf of California, separated by the Midriff Islands (Aubert and Lightner, 2000; De la Rosa-Vélez et al., 2000). Mourente and Rodriguez (1997) found that the Penaeus kerathurus postlarvae 8 days old at PL-V developmental stage had sufficient osmoregulatory capabilities to resist 25 psu in good conditions; consequently, those PL could migrate into estuarine habitats to pass from the pelagic to benthic life stage. Thus, although available evidence is not conclusive, damming the Colorado River may have reduced habitat quality in the UGC, but it remains as a nursery and growth area.

In conclusion, shrimp postlarvae recruit and grow in the Upper Gulf of California and Colorado River delta in spite of the high salinity found there. The baroclinic model predicts surface currents of about 8 $\mathrm{cm} \mathrm{s}^{-1}$ and suggests that PL found off the peninsula may come from different reproductive units than those found off the mainland coast. This would explain why postlarvae found in Santa Clara (mainland) are larger (and, presumably, older) than those from San Felipe (Baja California). However, the sampling design to observe the spawning population employed here would not detect reproductive units further offshore of the peninsula. Further work, specifically designed to examine larvae advection from the spawning grounds to the nursery area, needs to be conducted. Also, the precise location of the spawners as well as the mechanism that carries eggs and larvae to the nursery area remain to be studied.

\section{Acknowledgements}

This research was funded by CONACyT through grants 3876-T (Calderon-Aguilera) and 35351-T (Marinone) and by CICESE's regular budget (622143). The comments of two anonymous reviewers and M.F. Lavín helped to improve previous versions of this paper. J.M. Dominguez helped to prepare the figures.

\section{References}

Alvarez-Borrego, S., 2000. The Colorado River Estuary and Upper Gulf of California, Baja, Mexico. In: Seeliger, U., Kjerfve, B. (Eds.), Coastal Marine Ecosystems of Latin America. SpringerVerlag, Berlin Heidelberg, pp. 331-340.

Aragón-Noriega, E.A., Calderon-Aguilera, L.E., 2001. Age and Growth of Shrimp Postlarvae in the Upper Gulf of California. Aqua Journal of Ichthyology and Aquatic Biology 4, 99-104.

Aragón-Noriega, E.A., Cervantes Valle, C., García Juárez, A.R., Calderon-Aguilera, L.E., 1999. Evaluación del stock desovante de camarones peneidos del norte del Golfo de California. Revista Ciencia y Marina 9, 37-48.

Aubert, H., Lightner, V.V., 2000. Identification of genetic populations of the Pacific blue shrimp Penaeus stylirostris of the Gulf of California, Mexico. Marine Biology 137, 875-885.

Backhaus, J.O., 1983. A semi-implicit scheme for the shallow water equation for application to shelf sea modelling. Continental Shelf Research 2, 43-254.

Backhaus, J.O., 1985. A three-dimensional model for the simulation of shelf sea dynamics. Deutsche Hydrographisique Zeitschrift 38, 165-187.

Calderón-Pérez, J.A., Macias Regalado, E., Rendón Rodríguez, S., 1989. Clave de identificación para los estadios de postlarva y primeros juveniles de camarón del Género Penaeus (CRUSTACEA:DECAPODA) del Golfo de California, México. Ciencias Marinas 15, 57-70.

Carbajal, N., Souza, A., Durazo, R., 1997. A numerical study of the ex-ROFI of the Colorado River. Journal of Marine Systems 12, $17-33$.

Carrillo, L., Lavín, M.F., Palacios-Hernández, E., 2002. Seasonal evolution of the geostrophic circulation in the Northern Gulf of California. Estuarine, Coastal and Shelf Science 54, 157-173. 
Castro, R., Lavín, M.F., Ripa, P., 1994. Seasonal heat balance in the Gulf of California. Journal of Geophysical Research 99, 3249-3261.

Chapman, D.C., 1985. Numerical treatment of cross-shelf open boundaries in a barotropic coastal ocean model. Journal of Physical Oceanography 15, 1060-1075.

Crean, P.B., Murty, T.S., Stronach, J.A., 1988. Mathematical modelling of tides and estuarine circulation. Springer, New York.

De la Rosa-Vélez, J., Escobar-Fernández, R., Correa, F., MaquedaCornejo, M., de la Torre-Cueto, J., 2000. Genetic structure of two commercial penaeids (Penaeus californiensis and P. stylirostris) from the Gulf of California, as revealed by allozyme variation. Fishery Bulletin 98, 674-683.

Edwards, R.C., 1978. The fishery and fisheries biology of the penaeid shrimp on the Pacific Coast of Mexico. Oceanography and Marine Biology Annual Review 16, 145-180.

García, S., Le Restre, L., 1981. Life Cycles, Dynamics, Exploitation and Management of Coastal Penaeid Shrimp Stocks. FAO Fisheries Technical Paper. Rome.

Hernández-Ayón, M., Galindo-Bect, S., Flores-Baez, B.P., AlvarezBorrego, S., 1993. Nutrient concentrations are high in the turbid waters of the Colorado River delta. Estuarine and Coastal Shelf Science 37, 593-602.

Heron, M.L., Wang, H.X., Staples, D.J., 1994. Transport processes affecting Banana prawn postlarvae in the estuaries of the Gulf of Carpentaria. In: Sammarco, P.W., Heron, M.L. (Eds.), Coastal and Estuarine Studies - The Biophysics of Marine Larvae Dispersal. American Geophysical Union, Washington, DC, pp. $253-277$.

Hill, A.E., 1994. Horizontal zooplankton dispersal by diel vertical migration in $\mathrm{S}_{2}$ tidal currents on the northwest European continental shelf. Continental Shelf Research 14, 491-506.

Holtschmit, K.H., Romero, J.M., 1991. Maturation and spawning of blue shrimp Penaeus stylirostris (Stimpson) under hypersaline conditions. Journal of the World Aquaculture Society 22, 45-50.

Lavín, M.F., Sánchez, S., 1999. On how the Colorado River affected the hydrography of the Upper Gulf of California. Continental Shelf Research 19, 1545-1560.

Lavín, M.F., Beier, E., Badan, A., 1997a. Estructura hidrográfica y circulación del Golfo de California: Escalas estacional e interanual. In: Lavín, M.F. (Ed.), Contribuciones a la Oceanografía Física en México. Unión Geofísica Mexicana, Ensenada, Baja California, pp. 141-172.

Lavín, M.F., Durazo, R., Palacios, E., Argote, M.L., Carrillo, L., 1997b. Lagrangian observations of the circulation in the Northern Gulf of California. Journal of Physical Oceanography 27, 2298-2305.

Lavín, M.F., Godínez, V.M., Sánchez, S., 1998. Inverse-estuarine features of the Upper Gulf of California. Estuarine and Coastal Shelf Science 47, 769-795.

Mair, J.McD., 1979. The identification of postlarvae of four species of Penaeus (CRUSTACEA: DECAPODA) from the Pacific Coast of México. Journal of Zoology 188, 347-351.

Mair, J.McD., 1980. Salinity and water type preferences of four species of postlarval (Penaeus) from west México. Journal of Experimental Marine Biology and Ecology 45, 69-82.

Mair, J.McD., Watkins, J.L., Williamson, D.I., 1982. Factors affect- ing the migration of postlarval Penaeid shrimp into a Mexican Lagoon System. Oceanologica Acta, Proceedings International Symposium on Coastal SCOR/IABO/UNESCO; Bordeaux, France, pp. 339-345.

Marinone, S.G., Pond, S., Fyfe, J., 1996. A three-dimensional model of tide and wind induced residual currents in the central Strait of Georgia, B.C. 1996. Estuarine Coastal and Shelf Sciences 43, $157-182$.

Mathews, C.P., 1981. A review of the North American penaeid fisheries, with particular reference to Mexico. Kuwait Bulletin of Marine Science 2, 325-409.

Mourente, G., Rodriguez, A., 1997. Effects of salinity and dietary DHA $(22: 6 n-3)$ content on lipid composition and performance of Penaeus kerathurus postlarvae. Marine Biology 128, $289-298$

Orlanski, I., 1976. A simple boundary condition on unbounded hyperbolic flows. Journal of Computational Physics 21, 251-269.

Ouellet, P., Lefaivre, D., 1994. Vertical distribution of northern shrimp Pandalus borealis larvae in the Gulf of St. Lawrence; implication for trophic interactions and transport. Canadian Journal of Fisheries and Aquatic Science 51, 123-132.

Palacios-Hernández, E., Beier, E., Lavín, M.F., Ripa, P., 2002. The effect of seasonal variation on the circulation of the Northern Gulf of California. Journal of Physical Oceanography 32, 705-728.

Rady, M.A., El-Sabh, M.I., Murty, T.S., Backhaus, J.O., 1998. Residual circulation in the Gulf of Suez, Egypt. Estuarine, Coastal and Shelf Science 46, 205-220.

Rogers, B.D., Shaw, R.F., Herke, W.H., Blanchet, R.H., 1993. Recruitment of Postlarval and juvenile brown shrimp (Penaeus aztecus Ives) from offshore to estuarine water of the northernwestern Gulf of Mexico. Estuarine, Coastal and Shelf Science 36, 377-394.

Rothlisberg, P.C., 1982. Vertical migration and its effect on dispersal of penaeid shrimp postlarvae in the Gulf of Carpentaria, Australia. Fishery Bulletin 80, 541-554.

Rothlisberg, P.C., Church, J.A., Forbes, A.M.G., 1983. Modeling the advection of vertical migrating shrimp larvae. Journal of Marine Research 41, 511-538.

Rothlisberg, P.C., Church, J.A., Fandry, C.B., 1995. A mechanism for nearshore concentration and estuarine recruitment of postlarval Penaeus plebejus Hess (Decapoda, Penaidae). Estuarine, Coastal and Shelf Science 40, 115-138.

Rothlisberg, P.C., Craig, P.D., Andrewartha, J.R., 1996. Modelling penaeid prawn larval advection in Albattros Bay, Australia: defining the effective spawning population. Marine and Freshwater Research 47, 157-168.

Stronach, J.A., Backhaus, J.O., Murty, T.S., 1993. An update on the numerical simulation of oceanographic processes in the waters between Vancouver Island and the mainland: the GF8 model. Oceanography and Marine Biology: an Annual Review 31, 1-86.

Warner, R.R., Swearer, S.E., Caselle, J.E., 2000. Larval accumulation and retention: implications for the design of marine reserves and essential fish habitat. Bulletin of Marine Science 66, 821-830.

Wickins, J.F., 1976. Prawn biology and culture. Oceanography and Marine Biology Annual Review 14, 435-507. 